\title{
Cytotoxic effects and Identification of bioactive metabolites from crude extract of potential probiotic bacterium, Bacillus amyloliquefacians CS4, isolated from the gut of freshwater fish Channa striata (Bloch, 1793)
}

\author{
Nobel surya pandi durai $R^{1}$, Aiswarya $D^{2}$, Amutha $V^{3}$, Sethuraman $G^{4}$, Perumal $P^{5 *}$ \\ 1,2,3,4,5 Department of Biotechnology, School of Biosciences, Periyar University, Salem, Tamil Nadu, India, 636011
}

Available online at: www.isroset.org

Received: 23/May/2019, Accepted: 15/Jun/2019, Online: 30/Jun/2019

\begin{abstract}
In the present study, the crude secondary metabolites were extracted from the potential probiotic bacterium, Bacillus amyloliquefacians CS4 using solvent ethyl acetate and the cytotoxicity of bacterial extract was assessed against HeLa cell line through MTT assay. The crude extract exhibited cytotoxicity effect on HeLa cell lines with the effective half maximal inhibitory concentration $\left(\mathrm{IC}_{50}\right.$ ) value of $121.65 \mu \mathrm{g} / \mathrm{ml}$. The brine shrimp toxicity assay of crude extract revealed half maximal lethal concentration $\left(\mathrm{LC}_{50}\right.$ ) value at $93.377 \mu \mathrm{g} / \mathrm{ml}$ against Artemia salina. The zebra fish (Danio rerio) embryos were treated with different concentrations of extract upto $72 \mathrm{hpf}$ and was found lowest survivability (36.6 \%) at $200 \mu \mathrm{g} / \mathrm{ml}$ concentration. The bioactive compounds and their functional groups of crude extract were identified using GC-MS and FTIR analyses. The secondary metabolites produced by B. amyloliquefacians CS4 have caused potential cytotoxic effects on cancer cell line and these compounds could be possibly used for the development of therapeutic agents, in relation to cancer drug discovery.
\end{abstract}

Keywords- Anticancer activity, Bacillus amyloliquefacians, Secondary metabolites, Brine shrimp assay, GC-MS

\section{INTRODUCTION}

The investigations for less toxic and more effective metabolites from non-infective organisms are most required at present to overcome the resistance exhibited against the existing antibiotics. The bioactive compounds having anticancer activity are extracted from different microorganisms, terrestrial plants and marine life forms [1]. During the past, many important bioactive compounds with high therapeutic value have been reported from various bacteria [2].

The fish gastro intestinal tract (GI) is populated with complex microbial community and it plays a vital role in promoting the health of the host through the production of secondary metabolites. Probiotic bacteria are known to produce bioactive substances that protect them against predators [3]. These microbial bioactive substances exhibit antibacterial, antiviral, anti-tumour and cardio protective properties. Currently, cytotoxicity testing of several bioactive compounds in cell lines are being carried out by MTT assay, which determines cell viability based on mitochondrial function by measuring the activity of mitochondrial enzymes [4]. The bioactive compounds may cause adverse effects on the organisms upon treatment (e.g., humans, animals, or plants) or, in the case of aquaculture which could negatively affect the other organisms involved in fish or shellfish culture such as algae or live prey (e.g., rotifers and Artemia sp.). Hence, the toxicity of bioactive compounds on the target organisms should be tested and any adverse effect be ruled out before they can be applied. A complete toxicology assessment is a significant task and therefore a preassessment determine the effect of the bioactive products in many model eukaryotic systems such as Caenorhabditis elegans and Artemia sp. [5]. Since, the extracts from microbes could be a source of many striking molecules that could form leads towards drug discovery [6]. Some Bacillus spp. can produce several types of active compounds, for example the B. amyloliquefaciens possess $8.5 \%$ of the genome dedicated for the synthesis of secondary metabolites $[7,8]$.

In recent years, the roles of secondary metabolites in biological control, and the use of strains to produce metabolites as probiotics, have become an area of considerable research activity as they provide low technological and environmentally sustainable approaches for the inhibition of pathogens and improvements in the nutritional value of animal feeds [9]. Present investigation focusses on the therapeutic evaluation and identification of bioactive metabolites from B.amyloliquefacians CS4 isolated from gastro-intestinal tract of Channa striata. 


\section{MATERIALS METHODS}

\section{Strain isolation and culture condition}

The potential probiotic strain, B. amyloliquefacians CS4 was previously isolated from the gut of snake head fish (Channa striata), and identified by $16 \mathrm{~S}$ rRNA sequencing which was submitted on gene bank database (Genbank accession no. MK326902.1). Stock culture was stored in sterile LB broth containing $20 \%(\mathrm{v} / \mathrm{v})$ glycerol at $70^{\circ} \mathrm{C}$ and subculture was taken from the stock and then used for bioactive metabolites production.

\section{Organic solvent extraction}

An overnight broth culture of $B$. amyloliquefacians CS4 was inoculated into $250 \mathrm{ml}$ Luria Bertani (LB) broth $(25 \mathrm{~g} / \mathrm{L})$ and incubated at $37^{\circ} \mathrm{C}$ with shaking incubator for 2 to 3 days, the cells were removed by centrifugation at $10,000 \mathrm{rpm}$ for 15 $\min$ at $4^{\circ} \mathrm{C}$. The supernatant was subjected to solvent extraction sequentially with equal amounts of solvent ethyl acetate using separating funnel. The obtained supernatant was extracted exhaustively with ethyl acetate and after evaporation of the solvent at $44^{\circ} \mathrm{C}$ under vacuum the concentrated residue was collected and used for toxicity analysis.

\section{MTT Cytotoxicity Assay}

Anticancer property of crude extract was carried out by MTT [3-(4,5-dimethylthiazol-2-yl)-2,5-diphenyltetrazolium

bromide] method against HeLa cell lines. The cell lines were grown in Dulbecco's Modified Eagle Medium (DMEM) was supplemented with $10 \%$ fetal bovine serum (FBS) and $100 \mu \mathrm{g} / \mathrm{ml}$ streptomycin. The cell suspension $100 \mu \mathrm{l}$ was seeded into 96-well plates at a plating density of 10,000 cells/well and incubated to allow for cell attachment at $37^{\circ} \mathrm{C}$, $5 \% \mathrm{CO}_{2} 95 \%$ air and $100 \%$ relative humidity. After $24 \mathrm{~h}$, $100 \mu \mathrm{l}$ of the medium containing the crude extract at various concentrations $(0,12.5,25,50,100$ and $200 \mu \mathrm{g} / \mathrm{ml})$ was added and incubated at for $48 \mathrm{~h}$. Triplicate was maintained, and the medium containing without extracts were served as control. After $48 \mathrm{~h}$ of incubation, $15 \mu \mathrm{l}$ of MTT $(5 \mathrm{mg} / \mathrm{ml})$ in phosphate buffered saline (PBS) was added to each well and incubated at $37^{\circ} \mathrm{C}$ for $4 \mathrm{~h}$. The medium with MTT was then flicked off and the formed formazan crystals were solubilized in $100 \mu \mathrm{l}$ of DMSO and then measured the absorbance at 570 $\mathrm{nm}$ using micro plate reader.

\section{Brine shrimp toxicity assay}

Cytotoxicity potential of the crude metabolites was tested against brine shrimp (A. salina) larvae according to brine shrimp lethality test (BSLT) method 24 well plates. The lethality bioassay was performed using 25 nauplii for each sample of the crude extract, which was tested with varied concentrations viz; $0,12.5,25,50,100$ and $200 \mu \mathrm{g} / \mathrm{ml}$ in artificial seawater and the assay was carried out in triplicate. The vials were maintained at room temperature for $24 \mathrm{~h}$ under the light and mortality of larvae was calculated, and their lethal concentration at $50 \%\left(\mathrm{LC}_{50}\right)$ was estimated using probit analysis.

\section{Embryo toxicity assay}

Zebrafish embryo toxicity test (ZFET) for crude extract was performed according to the Organisation for Economic Cooperation and Development (OECD) guidelines. The embryos were exposed to different concentrations and the control was maintained without the treatment of extracts in the 24 well plates. The ten zebra fish (D. rerio) embryos were used per concentration of sample and also the control, where each test sample was performed in triplicates. The test wells treated with samples were incubated at $27 \pm 1{ }^{\circ} \mathrm{C}$. Toxic and teratogenic effects were examined using a light microscope at every 3, 6, 12, 24, 48 and $72 \mathrm{~h}$ post-treatment, respectively. The treated embryos were observed for the survivability (\%) and also their mortality and malformations were recorded [10].

\section{Gas chromatography-mass spectrometry analysis}

The crude extract of B. amyloliquefacians CS4 was undergone for the detection of bioactive molecules by Gas chromatography-mass spectrometry (GC-MS). It was analysed using Perkin Elmer Clarus 500 gas chromatography equipped with an Elite-5 capillary column (5\% Phenyl 95\% dimethylpolysiloxane) $(30 \mathrm{~m} \times 250 \mu \mathrm{m}, 0.25 \mu \mathrm{m}$ film thickness $)$ and mass detector turbomass gold of the company which was functioned in EI mode. The sample $(10 \mu \mathrm{l})$ injected into the column and Helium was the carrier gas at a constant flow rate of $1.0 \mathrm{ml} / \mathrm{min}$. The oven temperature was initially set to $70^{\circ} \mathrm{C}$, and $4 \mathrm{~min}$ after injection, it was increased to $200^{\circ} \mathrm{C}$ at a rate of $3^{\circ} \mathrm{C} / \mathrm{min}$ and gradually increased up to $300^{\circ} \mathrm{C}$ final temperature. The mass spectrometry was operated at electron impact ionization mode at $70 \mathrm{eV}$. Detection was achieved using an MS detector in an electron impact mode and a fullscan monitoring mode (m/z 30-600), with an acquisition rate of $20 \mathrm{spectra} / \mathrm{sec}$. The identification of components was based on comparison of their mass spectra with NIST and WILEY library.

\section{FT-IR spectral analysis}

Fourier transform infrared spectroscopy (FTIR) analysis of extract was performed using Perkin-Elmer, Lamda 2000, and the sample was recorded in the mid-IR region $\left(4000-400 \mathrm{~cm}^{-}\right.$ ${ }^{1}$ ) and the associated functional groups were determined.

\section{RESUltS}

\section{MTT Cytotoxicity Assay}

The cytotoxicity of crude extract against HeLa cell line treated with different concentrations (Fig. 1) was graphically represented in figure 2 . The percentage of inhibition of HeLa cells after treatment with bacterial extracts were: $9.17 \%$

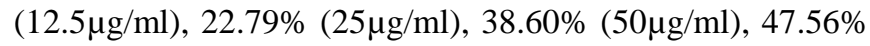


$(100 \mu \mathrm{g} / \mathrm{ml})$ and $62.70 \%(200 \mu \mathrm{g} / \mathrm{ml})$. The crude extract of $B$. amyloliqufacians exhibited significant activity against the HeLa cell line with an $\mathrm{IC}_{50}(50 \%$ growth inhibition) value of 121.65 $\mu \mathrm{g} / \mathrm{ml}$ (Fig.2).

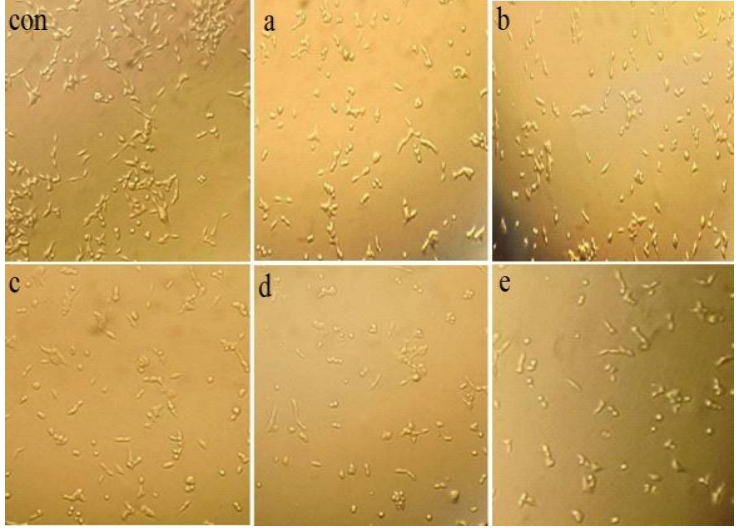

Fig. 1: B. Amyloliquefaciens crude extract treated HeLa cell lines at different concentration along with control, con) control, a) $12.5 \mu \mathrm{g} / \mathrm{ml}$, b) $25 \mu \mathrm{g} / \mathrm{ml}$, c) $50 \mu \mathrm{g} / \mathrm{ml}$, d) $100 \mu \mathrm{g} / \mathrm{ml}$, e) $200 \mu \mathrm{g} / \mathrm{ml}$

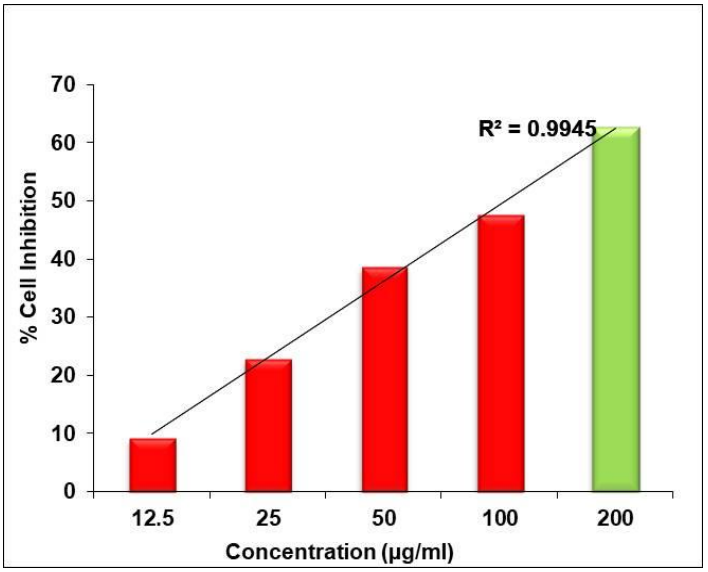

Fig. 2: The cytotoxic Growth Inhibition of $B$. Amyloliquefaciens crude extract on HeLa cell lines $\left(\mathrm{IC}_{50}=121.65 \mu \mathrm{g} / \mathrm{mL}, \mathrm{R}^{2}=0.994\right)$.

\section{Brine shrimp toxicity assay}

The cytotoxic effect of the crude metabolites was evaluated against brine shrimp (Artemia salina) larvae to assess its lethality profile and the result are shown in figure 3 . The morphological changes in the treated (dead) and untreated (control) Artemia nauplii were observed under Stereomicroscope (Fig. 4). The crude extract showed 0.33, 14.6, 28.6, 49.33 and $77.33 \%$ mortality at 12.5, 25, 50, 100 and $200 \mu \mathrm{g} / \mathrm{mL}$ concentration, respectively. The $\mathrm{LC}_{50}$ value was found to be $93.377 \mu \mathrm{g} / \mathrm{ml}$ which was considered moderately toxic and no mortality found in negative control (DMSO) group.
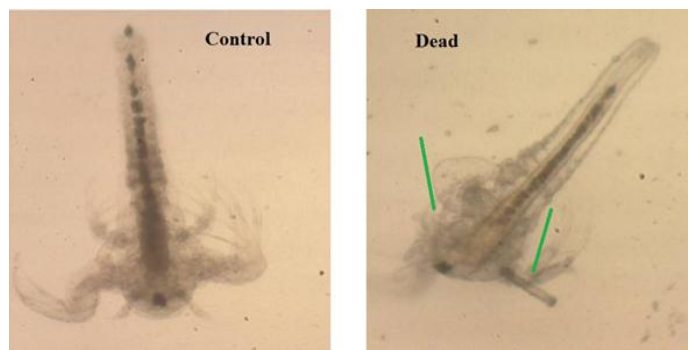

Fig. 3: Effect of crude extract on brine shrimp after $24 \mathrm{~h}$ treatment, morphology of control and treated dead larvae of Artemia salina.

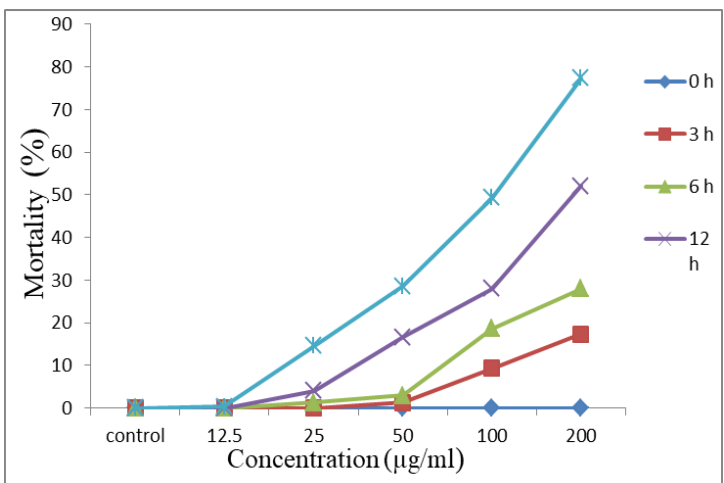

Fig. 4: Graphical representation of toxicity of brine shrimp at different concentration of bacterial extract after $24 \mathrm{~h}$

treatment, $\mathrm{LC}_{50}$ value $=93.37 \mu \mathrm{g} / \mathrm{ml}, \mathrm{LC}_{90}$ value $=369.54$ $\mu \mathrm{g} / \mathrm{ml}$. Chi-Square $(\chi 2)=10.09$ at $\mathrm{p}>0.05$ significant level.

\section{Embryo toxicity}

The survivability rate of zebra fish (D. rerio) embryos after $3,6,12,24,48$, and $72 \mathrm{hpf}$ of exposure in varying concentrations of crude metabolites are shown in figure 5. Survival rate and gross morphological changes were examined upto $72 \mathrm{hpf}$ and the lowest survivability (36.6\%) was found at $200 \mu \mathrm{g} / \mathrm{ml}$ concentration. However, at 3, 6, 12 and $48 \mathrm{hpf}$, no mortality was observed in embryos exposed at lower concentrations $(12.5,25$ and $50 \mu \mathrm{g} / \mathrm{ml})$ and shows $100 \%$ survivability (Fig. 6). The increased death ratio was observed in embryos exposed at higher concentrations (100 and $200 \mu \mathrm{g} / \mathrm{ml}$ ) after further exposure of 72 hours.

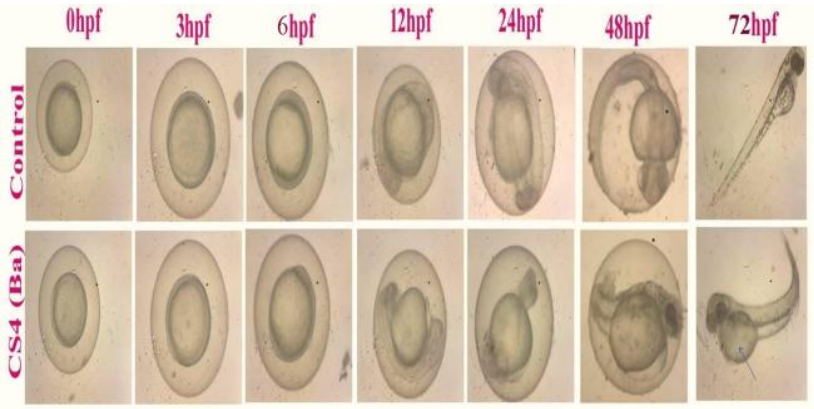

Fig. 5: The morphological changes in the crude extract treated Zebrafish embryos at different developmental stages. 


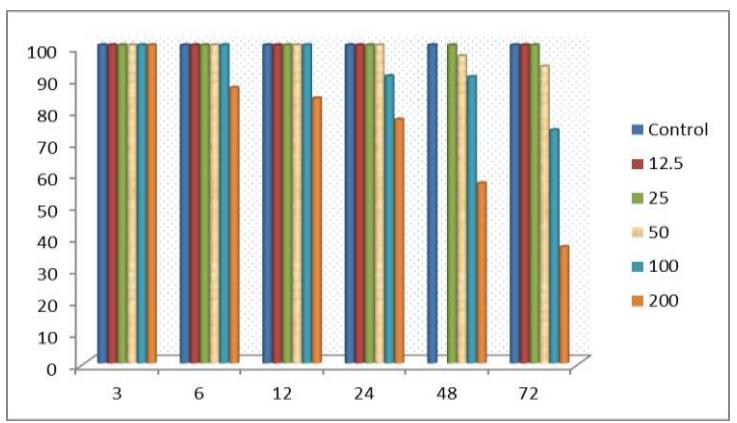

Fig. 6: Graphical representation of survivability (\%) of zebrafish embryos treated with different concentrations crude extract up to $72 \mathrm{hpf}$

\section{Gas chromatography-mass spectrometry analysis}

In order to identify the structural features of bioactive compounds present in the ethyl acetate crude extract, the extract was subjected to GC-MS analysis and was identified in relation to their retention time using Standard NIST and WILEY library (Table 1). Totally 17 compounds were identified from ethyl acetate extract of B. amyloliquefacians. The major compounds present in the extract are (Pyrrolo[1,2a]pyrazine-1,4-dione, hexahydro-3-(phenylmethyl)-(71.32\%), Naphthalene, decahydro-2,6-dimethyl (4.14\%), 3-Pyrrolidin2-yl-propionic acid (3.54\%), 2-Cyclopentanedione, 3,3,5,5tetramethyl (2.58\%), Phenol, 3,5-dimethoxy- (2.29\%), 1Proline-allyloxycarbonyl-, hexyl ester (2.71\%), and Dibutyl phthalate $(1.51 \%)$. The biological applications of the major compounds present in the crude extract were studied for their therapeutic significance.

\section{FT-IR spectral analysis}

To recognize the diverse functional groups found in bacterial extract, the extract was characterized under FT-IR. The major peaks were at 3343.54 (Dimer OH stretch; Carboxylic acids), 2946.40 (CH stretch; Alkanes), 2833.41 (Dimer $\mathrm{OH}$ stretch; Carboxylic acids), 2042.48 (N=C; misc), 1649.92 ( $\mathrm{C}=\mathrm{C}$ stretch; Alkenes), 1535.31 ( $\mathrm{NH}$ out of place; amides), 1451.17 (CH2 and CH3; Alkanes), 1402.75 (C-O stretch; Carboxylic acids), 1258.75 (C-F stretch; Alkyl halides), 1113.22 (C-F stretch; Alkyl halides), 1022.16 (C-F stretch; Alkyl halides) and $680.33 \mathrm{~cm}^{-1}$ (C-H bend; alkanes) (Fig. 7).

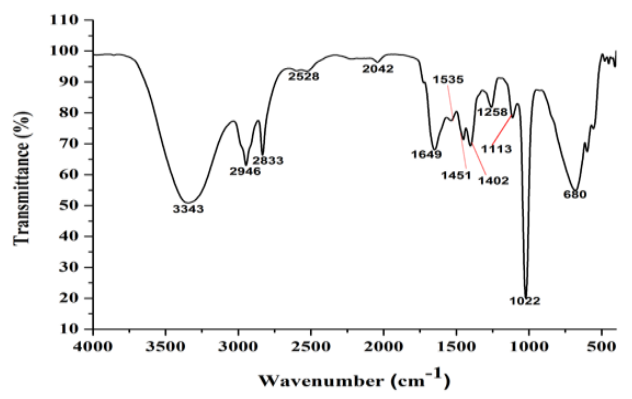

Fig. 7: The FT-IR spectrum of crude extract of $B$. amyloliquefaciens
Table 1: Bioactive compounds present in the crude extract were identified by GC-MS analysis.

\begin{tabular}{|c|c|c|c|c|}
\hline Peak & RT & Compound name & $\begin{array}{c}\text { Mol. } \\
\text { formula }\end{array}$ & $\begin{array}{c}\text { Area } \\
(\%)\end{array}$ \\
\hline 1 & 8.770 & $\begin{array}{c}\text { Naphthalene, decahydro- } \\
\text { 2,6-dimethyl }\end{array}$ & $\mathrm{C}_{20} \mathrm{H}_{38}$ & 0.53 \\
\hline 2 & 8.929 & $\begin{array}{l}\text { Naphthalene, decahydro- } \\
\text { 2,3-dimethyl- }\end{array}$ & $\mathrm{C}_{12} \mathrm{H}_{22}$ & 1.07 \\
\hline 3 & 9.223 & $\begin{array}{c}\text { Naphthalene, } \\
\text { decahydro-1,5-dimethyl }\end{array}$ & $\mathrm{C}_{18} \mathrm{H}_{34}$ & 0.85 \\
\hline 4 & 9.424 & $\begin{array}{c}\text { Naphthalene, decahydro- } \\
\text { 2,3-dimethyl }\end{array}$ & $\mathrm{C}_{12} \mathrm{H}_{22}$ & 1.17 \\
\hline 5 & 9.625 & $\begin{array}{c}\text { 2(1H)-Naphthalenone, } \\
\text { octahydro-4a-methyl- } \\
\text {,trans }\end{array}$ & $\mathrm{C}_{13} \mathrm{H}_{20} \mathrm{O}_{3}$ & 0.82 \\
\hline 6 & 9.701 & $\begin{array}{c}\text { Naphthalene, decahydro- } \\
\text { 1,5-dimethyl- }\end{array}$ & $\mathrm{C}_{12} \mathrm{H}_{22}$ & 0.52 \\
\hline 7 & 12.268 & Caryophyllene & $\mathrm{C}_{15} \mathrm{H}_{24}$ & 0.97 \\
\hline 8 & 13.241 & $\begin{array}{c}\text { Phenol, 2,4-bis(1,1- } \\
\text { dimethylethyl) }\end{array}$ & $\mathrm{C}_{22} \mathrm{H}_{30} \mathrm{O}$ & 0.86 \\
\hline 9 & 15.741 & $\begin{array}{l}\text { 3-Pyrrolidin-2-yl- } \\
\text { propionic acid }\end{array}$ & $\mathrm{C}_{7} \mathrm{H}_{13} \mathrm{NO}_{2}$ & 2.43 \\
\hline 10 & 16.026 & $\begin{array}{l}\text { 3-Pyrrolidin-2-yl- } \\
\text { propionic acid }\end{array}$ & $\mathrm{C}_{7} \mathrm{H}_{13} \mathrm{NO}_{2}$ & 1.11 \\
\hline 11 & 16.261 & $\begin{array}{c}\text { Pyrrolo[1,2-a]pyrazine- } \\
\text { 1,4-dione,hexahydro }\end{array}$ & $\mathrm{C}_{10} \mathrm{H}_{14} \mathrm{~N}_{2} \mathrm{O}_{2}$ & 4.70 \\
\hline 12 & 16.856 & $\begin{array}{c}\text { Pyrrolo[1,2-a]pyrazine- } \\
\text { 1,4-dione,hexahydro-3-(2- } \\
\text { methylpropyl) }\end{array}$ & $\mathrm{C}_{11} \mathrm{H}_{18} \mathrm{~N}_{2} \mathrm{O}_{2}$ & 11.09 \\
\hline 13 & 17.100 & Hydantoin, 1-butyl- & $\mathrm{C}_{7} \mathrm{H}_{12} \mathrm{~N}_{2} \mathrm{O}_{2}$ & 1.01 \\
\hline 14 & 17.141 & $\begin{array}{c}\text { 1,2-Cyclopentanedione, } \\
\text { 3,3,5,5-tetramethyl }\end{array}$ & $\mathrm{C}_{9} \mathrm{H}_{14} \mathrm{O}_{2}$ & 2.58 \\
\hline 15 & 17.259 & Dibutyl phthalate & $\mathrm{C}_{16} \mathrm{H}_{22} \mathrm{O}_{4}$ & 1.51 \\
\hline 16 & 17.838 & $\begin{array}{l}\text { Pyrrolo[1,2-a]pyrazine- } \\
\text { 1,4-dione,hexahydro-3-(2- } \\
\text { methylpropyl) }\end{array}$ & $\mathrm{C}_{11} \mathrm{H}_{18} \mathrm{~N}_{2} \mathrm{O}_{2}$ & 7.42 \\
\hline 17 & 18.031 & $\begin{array}{c}\text { Pyrrolo[1,2-a]pyrazine- } \\
\text { 1,4-dione,hexahydro-3-(2- } \\
\text { methylpropyl) }\end{array}$ & $\mathrm{C}_{11} \mathrm{H}_{18} \mathrm{~N}_{2} \mathrm{O}_{2}$ & 20.66 \\
\hline 18 & 18.123 & $\begin{array}{c}\text { Pyrrolo[1,2-a]pyrazine- } \\
\text { 1,4-dione,hexahydro-3-(2- } \\
\text { methylpropyl) }\end{array}$ & $\mathrm{C}_{11} \mathrm{H}_{18} \mathrm{~N}_{2} \mathrm{O}_{2}$ & 3.67 \\
\hline 19 & 18.173 & Phenol, 3,5-dimethoxy- & $\mathrm{C}_{8} \mathrm{H}_{10} \mathrm{O}_{3}$ & 2.29 \\
\hline 20 & 20.153 & 2,5-Piperazinedione, 3- & $\mathrm{C}_{12} \mathrm{H}_{14} \mathrm{~N}_{2} \mathrm{O}_{2}$ & 0.59 \\
\hline
\end{tabular}




\begin{tabular}{|c|c|c|c|c|}
\hline & & methyl-6-(phenylmethyl) & & \\
\hline 21 & 20.254 & $\begin{array}{c}\text { o-Butyl O,O-diethyl } \\
\text { phosphorothioate }\end{array}$ & $\mathrm{C}_{8} \mathrm{H}_{19} \mathrm{O}_{3} \mathrm{PS}$ & 1.35 \\
\hline 22 & 20.480 & $\begin{array}{l}\text { Cyclopentane, } 1,2,4- \\
\text { trimethyl- }\end{array}$ & $\mathrm{C}_{8} \mathrm{H}_{16}$ & 0.89 \\
\hline 23 & 20.891 & $\begin{array}{l}\text { Pyrrolo[1,2-a]pyrazine- } \\
\text { 1,4-dione,hexahydro-3-(2- } \\
\text { methylpropyl) }\end{array}$ & $\mathrm{C}_{11} \mathrm{H}_{18} \mathrm{~N}_{2} \mathrm{O}_{2}$ & 1.92 \\
\hline 24 & 21.034 & $\begin{array}{c}\text { Succinic acid, 2,6- } \\
\text { dimethoxyphenyl ethyl } \\
\text { ester }\end{array}$ & $\mathrm{C}_{14} \mathrm{H}_{18} \mathrm{O}_{6}$ & 0.74 \\
\hline 25 & 21.118 & $\begin{array}{c}\text { 2,5-Piperazinedione, 3- } \\
\text { benzyl-6-isopropyl }\end{array}$ & $\mathrm{C}_{14} \mathrm{H}_{18} \mathrm{~N}_{2} \mathrm{O}_{2}$ & 1.09 \\
\hline 26 & 21.755 & $\begin{array}{l}\text { Pyrrolo[1,2-a]pyrazine- } \\
\text { 1,4-dione,hexahydro-3- } \\
\text { (phenylmethyl) }\end{array}$ & $\mathrm{C}_{14} \mathrm{H}_{16} \mathrm{~N}_{2} \mathrm{O}_{2}$ & 4.00 \\
\hline 27 & 22.133 & $\begin{array}{l}\text { Pyrrolo[1,2-a]pyrazine- } \\
\text { 1,4-dione,hexahydro-3- } \\
\text { (phenylmethyl) }\end{array}$ & $\mathrm{C}_{14} \mathrm{H}_{16} \mathrm{~N}_{2} \mathrm{O}_{2}$ & 18.47 \\
\hline 28 & 22.619 & Ethisterone & $\mathrm{C}_{21} \mathrm{H}_{28} \mathrm{O}_{2}$ & 1.14 \\
\hline 29 & 24.549 & $\begin{array}{c}\text { 1-Proline, } \mathrm{N}- \\
\text { allyloxycarbonyl-, nonyl } \\
\text { ester }\end{array}$ & $\mathrm{C}_{18} \mathrm{H}_{31} \mathrm{NO}_{4}$ & 1.85 \\
\hline 30 & 24.876 & $\begin{array}{c}\text { 1-Proline, } \mathrm{N}- \\
\text { allyloxycarbonyl-, hexyl } \\
\text { ester }\end{array}$ & $\mathrm{C}_{15} \mathrm{H}_{2} \mathrm{NO}_{4}$ & 2.71 \\
\hline
\end{tabular}

\section{DISCUSSION}

The bacterial form of Bacillus genus are abundant source of antimicrobials compounds, since many species of this genus synthesize antimicrobial peptides. These bacteria in general represent a new and rich source of secondary metabolites that need to be explored [11]. In this present study, the MTT assay results shown that the crude extract of $B$. amyloliquefaciens CS4 showed higher inhibition rate against HeLa cells at high concentration (than of low concentration). In an earlier study, it has been proved that the crude extract of B. amyloliquefaciens AK-0, a recently isolated bacterium exhibited anti-proliferative activity against human colorectal cancer cells such as HCT116, SW480, LoVo and HT-29 [12]. Similarly crude extracts of $B$. subtilis and $B$. thuringiensis isolated from different marine environments showed cytotoxicity against established HeLa cell lines [13, 14]. The present findings are in line with the earlier research finding that documented the extract anti HeLa cell lines at $\mathrm{IC}_{50}$ value of $121.65 \mu \mathrm{g} / \mathrm{ml}$. Several studies have shown that brine shrimp assay has been an excellent method for preliminary investigations of toxicity of biologically active compounds. The resulted mortality or toxic effect of the extracts on brine shrimp larvae could be due to the toxic compounds that possess ovicidal and larvicidal actions either by affecting the embryonic development or that would slay the eggs [15]. Hence, the cytotoxic effects of the bacterial extracts were articulated for the further cytotoxicity assay in future as it correlated with activity against the brine shrimp nauplii [16]. Zebrafish embryo toxicity model has been proposed as the most promising alternative approach to classical acute fish toxicity testing with live fish [17]. Higher fecundity and rapid development have allowed testing a number of samples at shorter duration. Moreover, the transparent nature of embryos makes them easy to visualize morphological and developmental abnormalities during testing [18]. The crude metabolites of $S$. bongori possess active compounds that showed extensively toxic effects on zebrafish- embryo as well as brine shrimps-larvae [19]. When compared to the present work to previous reports, the presently extracted bioactive compounds from the bacterium, B. amyloliquefaciens have evidenced their role in several applications (Table 1). The active principle compounds in the crude extract of B. amyloliquefaciens were reported earlier for their biological properties (https://pubchem.ncbi.nlm.nih.gov/). Some of the applications of the major active compounds were; Pyrrolo[1,2-a]pyrazine-1,4-dione, hexahydro-3-

(phenylmethyl) (Antibacterial agents, antifungal, antioxidative agent, anticancer activity), Naphthalene, decahydro-2,6-dimethyl (Antibacterial agents, Antineoplastic agents), 3-Pyrrolidin-2-yl-propionic acid (antipyretic or antiinflammatory agents) and Phenol, 3,5-dimethoxy(Antiasthmatics, Drugs for disorders of the urinary system). The major compound Pyrrolo[1,2-a]pyrazine-1,4dione,hexahydro-3-(phenylmethyl) isolated from marine sponge associated Bacillus species showed potential antioxidants and anticancer activity [20].

\section{CONCLUSION}

The present results suggest that the crude extract of $B$. amyloliquefaciens CS4 exhibited potential anticancer properties against HeLa cell line. The major 'pyrrol' derived compounds present in the crude extract could be responsible for the anticancer activity. The findings of this study revealed that probiotic bacterium, B. amyloliquefaciens CS4 has been found to produce bioactive secondary metabolites. The toxicity analysis on brine shrimps and zebrafish embryo result moderately toxic at increased concentration. In conclusion, the cytotoxicity exhibited by the crude extract was indicates the presence of potent bioactive compounds with potential application in pharmaceutical industry. This finding warrants further studies to isolate and elucidate the mechanism of bioactive components produced by $B$. amyloliquefaciens. 


\section{REFERENCES}

[1]. M.S. Butler, "Natural products to drugs: Natural productderived compounds in clinical trials", Natural Product Report, Vol. 25, pp475-516, 2008.

[2]. W.F. Safari, E. Chasanah, A.T. Wahyudi, “Antibacterial and anticancer activities of marine bacterial extracts and detection of genes for bioactive compounds synthesis", International Journal of Pharmacy and Pharmaceutical Science, Vol. 8, Issue. 2, pp. 55-59, 2016.

[3]. H. Sugita, Y. Hirose, N. Matsuo, and Y. Deguchi, "Production of the antibacterial substance by Bacillus sp. Strain NM 12, an intestinal bacterium of Japanese coastal fish", Aquaculture. Vol. 165, pp. 269-280, 1998.

[4]. R. Somayeh, R. Ali, H. Mehrdad and N. Tahereh, "Artemia salina as a model organism in toxicity assessment of nanoparticles". DARU Journal of Pharmaceutical Sciences, Vol. 23, DOI 10.1186/s40199-015-0105-x, 2015

[5]. A. K. Neu, M. Månsson, L. Gram, M.J. Prol-García, "Toxicity of Bioactive and Probiotic Marine Bacteria and Their Secondary Metabolites in Artemia sp. and Caenorhabditis elegans as Eukaryotic Model Organisms", Applied and Environmental Microbiology, Vo.1, pp. 146-153, 2013.

[6]. D.J. Newman, and G.M. Cragg, "Natural Products as Sources of New Drugs over the Last 25 Years", Journal of Natural Products, Vol. 70, pp. 461-477, 2007.

[7]. X.H. Chen, A. Koumoutsi, R. Scholz, A. Eisenreich, K. Schneider, I. Heinemeyer, B. Morgenstern, B. Voss, W.R. Hess, O. Reva, H. Junge, B. Voigt, P.R. Jungblut, J. Vater, R. Sussmuth, H. Liesegang, A. Strittmatter, G. Gottschalk and R. Borriss, "Comparative analysis of the complete genome sequence of the plant growth-promoting bacterium Bacillus Amyloliquefaciens Fzb42”, Nature Biotechnology, Vol. 25, pp. 1007-1014, 2007.

[8]. R.K. Ganguly, S. Midya, and S.K. Chakraborty, "Antioxidant and Anticancer Roles of a Novel Strain of Bacillus anthracis Isolated from Vermicompost Prepared from Paper Mill Sludge", BioMed Research International. Vol. 1, article ID 1073687, pp. 7, 2018.

[9]. E. Hinarejos, M. Castellano, I. Rodrigo, Bacillus subtilis IAB/BSO3 as a potential biological control agent, European Journal of Plant Pathology, Vol. 146, pp. 597-608, 2016.

[10]. R. Nagel, "Dar T: the embryo test with the zebrafish Danio rerioa general model in ecotoxicology and toxicology". Altex, Vol. 19, pp. 38-48, 2002.

[11]. E. Sansinenea and A. Ortiz, "Secondary metabolites of soil Bacillus spp.", Biotechnology Letters, Vol. 33, pp. 1523-1538, 2011.

[12]. G.H. Park, H.M. Song, Y.S. Kim, Y. Jeon, J.S. Koo, H.J. Jeong, \& J.B. Jeong, "Anti-cancer activity of Bacillus amyloliquefaciens $A K-0$ through cyclin D1 proteasomal degradation via GSK3 dependent phosphorylation of threonine-286", Die Pharmazie, Vol. 72, pp. 348-354, 2017.

[13]. R. Ramasubburayan, S. Sumathi, D. MagiBercy, G. Immanuel, and A. Palavesam, "Antimicrobial, antioxidant and anticancer activities of mangrove associated bacterium Bacillus subtilis RG", Biocatalysis and Agricultural Biotechnology, Vol. 4, pp. 158-165, 2015.

[14]. D. R. Ammons, J.D. Short, J. Bailey, G. Hinojosa, L. Tavarez, M. Salazar and J.N. Rampersad, "Anti-cancer Parasporin Toxins are Associated with Different Environments: Discovery of Two Novel Parasporin 5-like Genes", Current Microbiology, 2016 https://doi.org/10.1007/s00284-015-0934-3.
[15]. A. Manilal, S. Sujith, G.S. Kiran, J. Selvin, and C. "Shakir, Cytotoxic potentials of red algae, Laurencia brandenii collected from the Indian coast", Global Journal of Pharmacology, Vol. 3, pp. 90-94, 2009.

[16]. M.O. Ullah, M. Haque, K.F. Urmi, A.H.M. Zulfiker, E.S. Anita, M. Begum, K. Hamid, "Anti-bacterial activity and brine shrimp lethality bioassay of methanolic extracts of fourteen different edible vegetables from Bangladesh. Asian Pacific Journal of Tropical Biomedicine, Vol. 3, pp. 1-7, 2013.

[17]. R. Embry, S. E. Belanger, T. A. Braunbeck, "The fish embryo toxicity test as an animal alternative method in hazard and risk assessment and scientific research", Aquatic Toxicology, Vol. 97, pp. 79-87, 2010.

[18]. S. Glaberman, S. Padilla, and M.G. Barron, "Evaluating the zebrafish embryo toxicity test for pesticide hazard screening," Environmental Toxicology and Chemistry", Vol. 36, pp. 1221-1226, 2017.

[19]. G. Balasubramani, D. Arul, C. Kamaraj, P. Deepak, D. Aiswarya, K. Jothimani, P. Santhanam, P. Perumal, "Comparative extraction of Salmonella bongori derived metabolites and their toxicity on bacterial pathogens, mosquito-larvae, zebrafish-embryo and brine-shrimp: A modified approach", Ecotoxicology and Environmental Safety, Vol. 169, pp. 192-206, 2019.

[20]. M. Gopi, N. Balachandran Dhayanithi, K. Nanthini Devi, T. T. Ajith Kumar, "Marine natural product, Pyrrolo[1,2-a]pyrazine1,4-dione, hexahydro-(C7H10N2O2) of antioxidant properties from Bacillus species at Lakshadweep archipelago", Journal of Coastal Life Medicine, Vol. 2, pp. 636-641, 2014. 